Article

\title{
Dai Identity in the Chinese Ecological Civilization: Negotiating Culture, Environment, and Development in Xishuangbanna, Southwest China
}

\author{
Lily Zeng(1) \\ School of Forestry and Environmental Studies, Yale University, New Haven, CT 06511, USA; \\ lily.zeng@aya.yale.edu
}

Received: 2 August 2019; Accepted: 20 November 2019; Published: 25 November 2019

\begin{abstract}
The Ecological Civilization (Eco-Civilization) is a Chinese political framework to advance a renewed human-nature relationship that engenders a sustainable form of economic development, and its narratives provide political impetus to conserve ethnic minority cultures whose traditional practices are aligned with state-sanctioned efforts for environmental protection. This official rhetoric is important in Xishuangbanna, a prefecture in Yunnan province renowned for its lush tropical rainforests and Dai ethnic minority. This article explores the relationship between Dai cultural identity and the Chinese state in the context of environmental concerns and development goals. Historical analyses of ethnic policies and transformations of landscapes and livelihoods are presented alongside descriptions of contemporary efforts by Dai community members and the Chinese state to enact Eco-Civilization directives, and they illustrate paradoxical circumstances in which political rhetoric and practice are seemingly at odds with one another, yet often contradict in such ways so as to further the Chinese state agenda. Moreover, case studies demonstrate how new policies and sustainable development efforts have often perpetuated structures and ideologies of the Maoist era to reinforce inequalities between central state powers and already marginalized ethnic minorities. These dynamics warrant further consideration as the Chinese government continues to champion its leadership in environmental governance.
\end{abstract}

Keywords: political ecology; spiritual ecology; Ecological Civilization; civilizing projects; sustainable development; ethnic minorities; indigenous; Xishuangbanna; China

\section{Introduction}

Since its reform and opening-up in the late 1970s, China has successfully transitioned from a low-income to a high-middle-income country with significant economic achievements. At the same time, after an extended period of extensive and high-speed economic growth, China has paid a heavy environmental price with the emergence of problems such as air, water, and soil pollution, deforestation, biodiversity loss, tainted food, and other public health concerns (e.g., Shapiro 2001; Harris and Lang 2015; UNEP 2016). Tensions between economic development and environmental protection have been at the forefront of not only national discussions, but also international discussions since the mid-20th century. However, many historians can trace the alignment of these ostensibly antithetical concerns in 1992 at the Rio Earth Summit (Bernstein 2001), where Agenda 21 emphasized "sustainable development" as an organizing principle to offer a "win-win" outcome for "people with hitherto irreconcilable positions in the environment-development debate to search for common ground without appearing to compromise their positions" (Lélé 1991, p. 607).

This article examines "win-win" efforts to align economic development and environmental protection in China through initiatives involving ethnic minority Dai in Xishuangbanna Dai 
Autonomous Prefecture in Yunnan province. Among laypeople, Xishuangbanna is renowned for its exceptional natural beauty, which boasts China's richest concentration of biodiversity and the world's northernmost tropical rainforest (Kou and Zhang 1987; Wang and Jin 1987; Yang et al. 1987; Zhang and Cao 1995; Myers et al. 2000). Tourists are equally attracted to the cultural diversity that Xishuangbanna offers, in which Dai culture-often packaged in safe and appealing ways for Han or foreign consumers-is a highlight (Davis 2005; McCarthy 2009). However, rapid economic development from rubber cultivation has resulted in important social changes for Dai communities (Wu et al. 2001; Reuse 2010; Sturgeon 2010), as well as numerous environmental problems (Li et al. 2007; Hu et al. 2008; Qiu 2009; Chen et al. 2016; Zhang et al. 2019). Scholars have noted a history of intertwined economic and environmental concerns in Xishuangbanna, often coupled with political ideologies concerning the role of the Chinese state and the social rank of ethnic minorities (e.g., Sturgeon and Menzies 2006; Xu 2006; Sturgeon 2010; Hathaway 2013; Sturgeon et al. 2014; Zeng et al. 2017), and more recently, these connections have resurfaced in official state rhetoric for Ecological Civilization (often referred to as "Eco-Civilization"), a political framework from the Community Party of China (CPC) aimed at harmonizing economic development and environmental protection.

This article explores the application of Eco-Civilization ideology in Xishuangbanna through contemporary dynamics with Dai communities surrounding economic development, environmental protection, ethnic identity, and the role of the state, with an eye to how these relate to historical patterns since the 1950s. A section on political and theoretical considerations provides context for how under Eco-Civilization, ethnic minority Dai have become the objects of yet another state-initiated civilizing project, while simultaneously held up as virtuous examples of China's rich history, ethnic unity, and indigenous conservation. This is followed by a brief history on Dai as an ethnic group and a description of research methods. After these background sections, this paper traces how Dai ethnicity and culture have become sites of contest and negotiation for nation-building identity processes, environmental ideology, and development efforts by examining (1) ethnic rank and its relationship to landscapes and livelihoods, (2) the pursuit of development via community-based eco-tourism, and (3) Eco-Civilization in public signage that emphasizes parental authority from the Chinese state.

\section{Political and Theoretical Considerations}

Similar to the ethos of sustainable development, Eco-Civilization functions as a socio-technical imaginary that interweaves technological, political, social, and cultural values for the vision of a future society in which environmentally conscious citizens can enjoy comfortable lives supported by ecologically sustainable modes of resource extraction, production, and trade (Hansen et al. 2018). Importantly, the "state-initiated imaginary of Ecological Civilization is a promise to the population that with the right technologies and policies, and the heightened environmental consciousness of all citizens, a turn towards green need not reduce economic growth" (Hansen and Liu 2018, p. 323)-a promise tightened by what scholars have observed as the state's reliance on economic growth as a main guarantor for social stability and political legitimacy (Wang and Zheng 2000; Thøgersen 2003; Hansen and Liu 2018). First introduced in 2007 by Hu Jintao, this was endorsed as a major framework for the country's environmental laws and policies under President Xi Jinping's leadership in 2013. Since then, Eco-Civilization has continued to gain traction in Chinese society, and in 2018, it was elevated to a more prominent position in the constitution. In practice, Eco-Civilization has already become the ideological framework guiding new environmental policies and sustainable development efforts in China (e.g., Shen 2013; Yeh and Coggins 2014; Kostka and Nahm 2017; Ahlers and Shen 2018; Delman 2018), as well as instances of grassroots activism (e.g., Hansen and Liu 2018) and discussions surrounding research, journalism, and education (e.g., Duara 2014; Sawyer 2015).

Eco-Civilization【生文明】 (shēngtài wénming) is the fourth in the official series of China's civilization slogans, coming after Deng Xiaoping's Material Civilization and Spiritual Civilization 【物文明; 精神文明】 (wùzhí wénmíng; jīngshén wénmíng) and Jiang Zemin's Political Civilization 【政治文明】(zhèngzhì wénming) (Dynon 2008), in addition to other civilizing efforts from the 
Republican era (e.g., Harrell 1995b; Duara 2001; Thøgersen 2009). In these contexts, the term civilization, or “wenming" 【文明】 in Mandarin Chinese, describes a "historical process; and a kind of civility in terms of social etiquette and relations" (Dynon 2008, p. 83) for "a model life to which people must aspire" (Oswald 2014) ${ }^{1}$. This concept of civilization was introduced to China in the late 1800s through Japanese translations of European scholarship on history and society (Wang 1984; Duara 2001)2. European anthropologists at that time described human societies as progressing through stages of savagery and barbarism toward civilization (Fabian 1983). The CPC adopted this framework in the 1950s and 1960s to invest substantial effort and resources in a top-down mission of categorizing ethnic minorities according to socialist ideas of ethnic differences, inspired by its then ideological mentor, the USSR, and ranking them on a universal progression of history (Harrell 1995a; Davis 2005; Sturgeon and Menzies 2006; Xu 2006; Mullaney 2010). According to this ranking, the majority Han had reached a high level of social development, and less developed ethnic minorities were a historical glimpse into what Han society looked like centuries or even millennia ago (Sturgeon and Menzies 2006).

In China, discourse on civilization is often paralleled by discussions of sushi【素】, or social quality. Discourse on suzhi originates in 1980s state documents investigating rural poverty that attributed China's failure to modernize to the "low quality"【素低】(sùzhì dì) of its rural population (Anagnost 2004). Since then, the idea of suzhi has been extended from discourse on the social quality of the masses, usually in the context of backwardness and development, to encompass what moral and material characteristics define an individual of social quality (Anagnost 2004). Importantly, both wenming and suzhi discourse produce "hierarchies of value ... [that] effectively rank the worth of anyone or anything against criteria that are open to reinterpretation and change depending on the ideological policy emphasis at a given place and time" (Dynon 2008, pp. 97-98). These hierarchies of value have been deployed throughout various "civilizing projects" in China, "in which one group, the civilizing center, interacts with other groups (the peripheral peoples) in terms of a particular kind of inequality ... [that] has its ideological basis in the center's claim to a superior degree of civilization, along with a commitment to raise the peripheral peoples' civilization" (Harrell 1995a, p. 4). Eco-Civilization - with the Chinese state as the civilizing center and rural ethnic minorities as peripheral peoples-follows this description.

The imaginary of Eco-Civilization draws on previous civilization discourse and selective interpretations of China's history to construct a sense of cultural continuity and invoke a vision for the future rooted in a united national identity, particularly as a contrast to what is often portrayed in official Chinese discourse as the destructive industrial civilization of the West (Dynon 2008; Hansen et al. 2018). Alongside economic growth, observers have noted that defending China's national unity is a key source of political legitimacy for the CPC (Wang and Zheng 2000; Thøgersen 2003). However, national unity and identity, particularly when entwined with heterogenous ethnicities and cultural positionings, are complex issues in China, on which there is a plethora of scholarship (e.g., Harrell 1995b; Hansen 1999; Litzinger 2000; Gladney 2004; Crossley et al. 2006; McCarthy 2009; Mullaney 2010). In theory, the Han ethnic majority and 55 ethnic minorities comprise the multinational Chinese nation 【中民族】 (zhōnghuá minzú), in which “Chinese identity is supposedly not tied to any one racial or ethnic heritage" (McCarthy 2009, p. 4). In practice, it is frequently the case that "[t]o be ethnic is to be marginal, not part of the canon, not part of the established culture central to legitimacy of the state, not mainstream, not authoritative" (Crossley et al. 2006, p. 5).

These intra-nation-state complexities are often amplified in conversation with international discussions of environmental protection and indigeneity. With its emphasis on Eco-Civilization, the $\mathrm{CPC}$ has also adopted the position that conserving ethnic minority culture is important because

1 Wenming is an ancient word from the I Ching, but its meaning there differs from contemporary use; for an account of pre-modern Chinese conceptions of wenming, see Wang (1984)Wang

2 This was a complex historical process; see Duara (2001) for a detailed analysis of transformations in the discourse of civilization in the twentieth century and its multifaceted relationship with nationalism in East Asia. 
"environmental protection is naturally maintained by local indigenous cultures" (Wen et al. 2012, p. 32). Ethnic minorities in China are often conflated with indigenous groups by researchers and laypeople, but the political contexts of each term are nuanced in different ways. The CPC has supported indigenous rights movements in other countries settled by Europeans, but it resisted the notion that indigenous groups existed in China, particularly in relation to issues such as legal treaties or historical precedence (Gladney 2004). Instead, the concept of indigeneity was introduced to China on the heels of environmentalism, largely thanks to the efforts of a small group of scholars, most notably, the Chinese ethnobotanist Pei Shengji (Hathaway 2013). Pei significantly influenced the discourse in China surrounding human-nature relationships by connecting with international interest in biological diversity and its intersection with cultural diversity through his writings on sacred forests, which he henceforth christened "Holy Hills" for English readers (Pei 1985; Pei 1993), protected by ethnic minority Dai in Xishuangbanna. Pei presented Holy Hills as scientific examples of "indigenous conservation" by Dai communities, contradicting standard Han depictions of minorities as primitive peoples in need of state guidance for social development, and instead framing the knowledge and practices of ethnic minorities as models for conservation and sustainability (Hathaway 2013). His rebranding has successfully cast Holy Hills as sites of interest to conservation scientists (e.g., Liu et al. 2002; Zhu et al. 2004, 2010; Zeng 2018b) and Xishuangbanna National Nature Reserve (e.g., Ramachandran 2005), such that Holy Hills and their Dai guardians have become intimately connected to environmental concerns, as this article will discuss in more detail.

\section{Research among Ethnic Minority Dai in Xishuangbanna}

Soon after the founding of the People's Republic of China in 1949, the CPC began organizing the myriad diversity of people and lifestyles existing within its borders into tidy ethnic labels that continue to present day. The product of these efforts was "the invention of ethnic groups, not their discovery" (Keyes 1995, p. 148). In China, Dai as an ethnic categorization is the Mandarin Chinese version of Tai ${ }^{3}$, a term which refers to "people in mainland Southeast Asia, Southern China, and Northeastern India who are presumed to share not only related languages but also some essential 'ethnic' characteristics" (Keyes 1995, p. 136) ${ }^{4}$. Though the official category Dai includes multiple Tai peoples who live in other regions of Yunnan province and other Southeast Asian countries ${ }^{5}$, this article focuses on Dai people in Xishuangbanna, who are part of the Tai Lue people (Hsieh 1995; Davis 2005).

Xishuangbanna Dai Autonomous Prefecture【西版傣族自治州】 (Xīshuāngbănnà dăizú zìzhìzhōu) $\left(21^{\circ} 08^{\prime}-22^{\circ} 36^{\prime} \mathrm{N}, 99^{\circ} 56^{\prime}-101^{\circ} 50^{\prime} \mathrm{E}\right)$ covers $19,150 \mathrm{~km}^{2}$ of Yunnan province, Southwest China. This region is part of an area historically known as Sipsongpanna, which refers to the loose confederation of small political entities that formed an independent Tai kingdom founded during the late 1200s on the peripheries of the Chinese empire and various Southeast Asian principalities (Giersch 2006) Since the 1950s, Sipsongpanna has been under the direct rule of the CPC, and the region became

3 Shih-chung Hsieh describes the 1951 meeting in which Dai group representatives met in Beijing to discuss the Mandarin Chinese name for their people: “The representatives of Dehong suggested using Tai 泰 (as their name for themselves still is pronounced), but the Xishuangbanna members wanted to adopt a word with the sound dai. Finally, to settle the quarrel, Prime Minister Zhou Enlai synthesized the character 泰 and the radical 人 (which means "people") to create Dai 傣" (Hsieh 1995, p. 319).

4 "Tai" is not to be confused with "Thai," which usually refers to Tai-speaking peoples in Thailand or citizens of Thailand.

5 In particular, Dai includes Tai Lue, who span Xishuangbanna and other Southeast Asian countries, and Tai Neua, from the Dehong region of western Yunnan province. These groups did not share the same premodern genealogies or writing systems, and their spoken languages and writing systems, though linguistically related, are not mutually comprehensible (Keyes 1992; Hsieh 1995; Davis 2005).

6 This territory was divided into twelve (sipsong in Dai language) political entities called panna (pan means thousand and $n a$ means rice paddy in Dai language; the panna political territory is based on the idea of "one thousand rice paddies")-hence the name "Sipsongpanna" (Reuse 2010). However, Dai interlocuters have often remarked to me that only eight of the original twelve panna territories are part of China's Xishuangbanna-the remainder of which comprise parts of Laos, Myanmar, and Thailand-which has led to a joke among some Dai people that Xishuangbanna ought to be named "Baetbanna" (baet meaning eight in Dai language). 
formally known as Xishuangbanna, a Mandarin transliteration of Sipsongpanna (Reuse 2010). Much of Xishuangbanna's landscape has been shaped by Dai land management practices, which have historically included farming wet rice paddies, swidden agriculture and different types of agroforestry, collecting non-timber forest products, maintaining Holy Hills as community-protected areas, managing home gardens and temple gardens, and increasingly since the 1980s, cultivating rubber (Pei 1993; Cao et al. 2000; Wu et al. 2001; Guo et al. 2002; Xu et al. 2005; Gao 2010; Sturgeon 2010; Zeng and Reuse 2016). In addition to the aforementioned livelihoods and activities in the countryside, there are also many Dai individuals in larger townships or cities who work in tourism or are employed as white-collar workers in banks or local government, among other pursuits (Hansen 1999; Evans 2000; Davis 2005; McCarthy 2009).

Across these different lifestyles and livelihoods, religion has been repeatedly raised by Dai interlocuters and scholars as a marker of Dai identity (Hasegawa 2000; Davis 2005; Xu et al. 2005; McCarthy 2009; Gao 2010). The ancestors of the Dai people practiced polytheism before Theravada Buddhism was introduced in the middle of the Tang dynasty, about 700 A.D. (Xu et al. 2005; Gao 2010). As a remnant of their polytheistic cosmologies, the majority of Dai people in Xishuangbanna practice a syncretic form of Buddhism and polytheistic animism for a vibrant religious life that includes numerous activities at Buddhist temples, as well as rituals to honor ancestors and other spirits in Holy Hill forests that have since become objects of conservation interest (Liu et al. 2002; Zhu et al. 2004; Ramachandran 2005; Zhu et al. 2010; Zeng and Reuse 2016). Though Buddhism is the dominant religion among Dai people, there are certain Dai communities that, for various historical reasons, belong to other religions, including Christianity and Islam (Gao 2010).

I have been fortunate over the course of my research to spend approximately 18 months between 2011 and 2017 (with the bulk of this time from 2014-2015) in Xishuangbanna. Though my research interests began with conservation biology questions and conducting biodiversity surveys in Holy Hills, I found myself increasingly drawn into the surrounding Dai communities to begin asking research questions inspired by scholars of political ecology. My ethnographic field data collection largely took the form of semi-structured interviews and participation observation. My conversations with interlocuters were primarily in Mandarin Chinese, but often with Dai words and phrases interspersed, especially in reference to aspects of Dai spirituality or worldviews for which there were no easy Mandarin equivalents. Occasionally, I enlisted the help of a Dai-Mandarin interpreter when Dai conversations progressed beyond my limited Dai language abilities. In addition to my time with Dai villagers, I was also fortunate to gain insight and perspectives on the topics in this article from academic researchers, tourism operators, local government workers, and laypeople from various nationalities.

\section{Ethnic Rankings and Ideological Landscapes}

Many visitors who have come to marvel at Xishuangbanna- "the kingdom of plants and animals" in Chinese media and tourism advertisements-have noticed a curious sight: instead of lush wild jungles carpeting sweeping mountains, the slopes are often covered with row upon row of rubber trees. As of 2018, rubber occupies approximately $21 \%$ of the prefecture's land, over 400,000 ha (Qiu 2009; Zhang et al. 2019). The reality of rubber in Xishuangbanna today is the product of a complex history. Soon after the Chinese Revolution, China was confronted with a series of external threats to its territory, and China's war effort was facing a shortage of important raw materials-including rubber. In August 1951, the CPC approved a plan to establish over 533,000 ha of rubber, of which over 133,000 ha would be in Xishuangbanna (Sturgeon and Menzies 2006) ${ }^{7}$. The USSR, China's ideological mentor, sent two agronomists in the early 1950s to help Chinese scientists in identifying the most productive areas for cultivating rubber, and they completed their initial botanical studies at Dong Palai, the Holy Hill protected by the Dai village of Manyangguang (Sturgeon and Menzies 2006; Zhu et al. 2010). Shortly

7 The rest would be on Hainan Island, the only other location with tropical climate in China. 
afterwards, Xishuangbanna Tropical Botanical Garden (XTBG), now a flagship research institution and tourist attraction under the Chinese Academy of Sciences, was first established beside Manyangguang to study plants in Dong Palai (though it has since relocated).

By 1953, the planning began for the plantations that would shortly become state farms, the embodiment of a new type of industrialized production and social structure (Sturgeon and Menzies 2006; Xu 2006). Although the decision to be self-sufficient rubber producers was a practical response to a strategic need, the decisions guiding production instructions were ideological (Sturgeon and Menzies 2006; Xu 2006; Sturgeon 2010). The CPC divided the population into "advanced Han and backward minorities, with each group linked to particular land uses ... state farms produced rubber, while minority farmers, especially shifting cultivators, produced other crops in what was thought to be an unproductive manner'" (Sturgeon 2010, p. 323), subscribing to the belief that economic value was produced by people with high social value. This same logic could also apply to some extent in reverse, in which producing economic value can imbue social value. During fieldwork in summer 2011, I met a Dai rubber farmer from Manyangguang who proudly told me the happy news of his daughter's marriage to a Han farm worker and how she had moved to join her husband on a nearby state rubber plantation. It appeared that though his daughter was still performing the same agronomic tasks of cultivating rubber, this Dai farmer saw a marked distinction between tapping rubber on family land and working in a state rubber plantation among Han employees. It seemed that in his eyes, employment on a state farm elevated his daughter from peasant to state worker, and in a certain way through the equalizing process of marriage, from minority Dai to majority Han. ${ }^{8}$

In the state ethos of the Maoist era and beyond, not only were ethnic minorities were thought to be of low social quality, many of their land management practices were also painted as environmentally harmful (Zeng et al. 2017). This is not unique to China, as exemplified by the case of "slash-and-burn" (a pejorative term for swidden agriculture), a practice that has been targeted by international environmental campaigns for the past few decades to perpetuate the "myth ... that swidden cultivation of forested land is destructive and wasteful, and in the worst cases results in barren, useless grassland successions" (Dove 1983). Though many environmental NGOs remain staunchly opposed to swidden even today (e.g., Conservation International, World Wildlife Fund, EcoLogic, Rainforest Saver), scholarship since Harold Conklin's pioneering work on swidden (Conklin 1954; Conklin 1957) began a global shift towards seeing that swidden cultivation can in fact be "a productive use of the forests, indeed more productive than commercial logging in terms of the size of the population supported" (Dove 1983). For instance, many researchers have begun describing swidden in Xishuangbanna as a sustainable practice with benefits for the maintenance of tropical biodiversity (e.g., Guo and Padoch 1995; Pei and Xu 1997; Xu et al. 1997; Xu et al. 1999; Yin 2001; Wang and Young 2003; Mo et al. 2011) — a switch that was also supported by Pei Shengji's paradigm-shifting work in the 1980s and 1990s connecting Dai Holy Hills with international discussions of indigeneity and environmental protection (Hathaway 2013).

The relationship between ethnic minorities and rubber production also changed in the 1980s. The influx of Han youth between the late 1960s and 1979 greatly increased the state farm labor force; in 1980, the departure of the disillusioned "rusticated youth"【知青】 (zhīqing) resulted in a severe labor shortage that nearly collapsed many state farms (Xu 2006) ${ }^{9}$. With no other options, the state farms finally began considering the surrounding ethnic minority population as potential participants in the social and economic transformations represented by industrialized state farms. Although in hindsight the decision to include minorities on state farms was an extremely successful economic maneuver, nine

8 These sentiments are not ubiquitous and continue to change among Dai rubber producers, particularly as Dai smallholder farms become more economically successful and state rubber farms stagnate (see Sturgeon 2010).

9 Of course, Han migrants to Xishuangbanna are not a homogenous group. Hansen (2005) describes distinctions between state-organized Han migrants who arrived to Xishuangbanna during the Maoist era and independent Han migrant who came in the reform era in search of economic opportunities, as well as class differences within these groups. 
of the eleven state farms in Xishuangbanna initially rejected the proposal to include ethnic minorities by "arguing that minority people 'lacked culture' and 'couldn't work'" (Sturgeon and Menzies 2006, p. 28) - in other words, claiming that the uncivilized and primitive nature of ethnic minorities rendered them categorically unworthy of contributing to the modernity that rubber represented.

By the early 1980s, there was a new understanding that local state governments should coach minority farmers in economic development, which prompted a series of policy changes and smallholder rubber campaigns to help state rubber farms meet the rising national demand for rubber while simultaneously providing a civilizing influence to ethnic minorities (Xu 2006; Sturgeon 2010). These efforts were also often coupled with environmental protection initiatives. For instance, during the 1990s, the MacArthur Foundation funded a conservation-as-development project, implemented by state-funded researchers, to eradicate the "backward" practice of swidden agriculture and replace it with rubber (Wang and Duan 1996). Strongly influenced by Western environmentalist ideals of "wilderness" in which nature is valued for being ostensibly untouched by humans (Cronon 1995), this foreign-funded and state-implemented project tried to separate people and nature. Ethnic minorities were discouraged from swidden activities in "pristine forests," which were curated as nature parks for tourists ${ }^{10}$. Moreover, Xishuangbanna's ethnic minorities farmers were encouraged to replace swidden practices with "modern" rubber cultivation, an act which the official narrative characterized as replacing rural farmers' ignorance with the state's superior knowledge (Zeng et al. 2017).

Ironically, rubber is now blamed by the scientific community as the major cause of deforestation and biodiversity loss in Xishuangbanna (Li et al. 2007; Hu et al. 2008; Qiu 2009; Chen et al. 2016; Zhang et al. 2019), as well as elsewhere in Southeast Asia (Ziegler et al. 2009). Swidden, meanwhile, is being praised as sustainable in the socioecological contexts in which it is or was practiced-in Menglun county, swidden land cover dropped from $27.57 \%$ to $0.46 \%$ from 1988 to 2006 (Hu et al. 2008)—and scientists are finding that swidden is beneficial for the maintenance of biodiversity (e.g., Guo and Padoch 1995; Pei and Xu 1997; Xu et al. 1997, 1999; Yin 2001; Wang and Young 2003; Mo et al. 2011). Swidden's change in reputation from negative to positive has been marked by a shift in descriptors in state, academic, and popular vernacular from "backward" to "traditional." Moreover, in 2015 Xishuangbanna's prefectural government started considering the development of an Ethnoecology Park to convert low-productivity rubber fields into a living museum showcasing traditional swidden practices, exemplifying how "a shift away from state rejection of swidden knowledge and practice takes place when the potential for state-approved swiddens arises in the form of a state-sanctioned park for tourists seeking to see the Dai 'tradition'" (Zeng et al. 2017, p. 170).

In the context of Eco-Civilization, land use practices such as swidden agriculture have arisen in portrayals such as the following:

Over thousands of years, traditional multifunctional agriculture, originally maintained by village and small household farming, was able to develop and apply what are essentially systems of eco-environmental sustainability. This has been gradually recognized as important, not because of modern education or mainstream institutions, but because of the challenges of global warming in adversely affecting yields and incidents of low food safety and quality. Most developing countries and regions in Asia, like rural China, have regional agriculture that can be congruent with the characteristics of nature of heterogeneity and diversity that will be essential for an ecological civilization. (Wen et al. 2012, pp. 33-34).

Thus, whereas ethnic minorities and their land use practices were previously denigrated as uncivilized and environmentally harmful, their contemporary branding is much more positive. At the same time, the ethnic minorities remain the objects of civilizing campaigns in the form of

10 This process was reminiscent of the creation of national parks in the USA in the late-1800s, beginning with the forcible removal of Native Americans from Yellowstone National Park to allow tourists and preservationists an unmarred experience of wilderness (Cronon 1995; Spence 1999). 
well-intentioned conservation initiatives. Throughout my fieldwork, I met passionate researchers and officials committed to working with local communities and teaching villagers how to protect the environment. State-funded research projects and conservation initiatives in China and Southeast Asia have been meticulously conducted to explore intercropping and other agroforestry techniques in monoculture rubber plantations as a means of reducing environmental and economic risks (e.g., Commercon 2016; Min et al. 2017; Penot et al. 2017; Dove 2018), but in Xishuangbanna, ethnicity has been identified as one of the "[m]ajor factors of adoption" (Min et al. 2017, p. 223) for these improved cultivation practices among smallholder rubber farmers. Agroforestry, meanwhile, has long been practiced by ethnic minority farmers in Xishuangbanna before and throughout the advent of rubber (Saint-Pierre 1991). Thus, although the content of the Eco-Civilization dogma has ostensibly altered narratives surrounding ethnic minorities, the embedded power dynamics between the central state as the civilizing center and rural ethnic minorities as peripheral peoples remain unchanged. Furthermore, as the following sections will also illustrate, initiatives and institutions inspired by Eco-Civilization often neglect to treat ethnic minorities as the experts of their own cultures, nor do they trust ethnic minority traditions in the hands of ethnic minorities themselves.

\section{Holy Hill Eco-Tourism and the Development Catch-22}

The Dai village Manyangguang protects Dong Palai, a Holy Hill that houses a sacred colorful rock (in Dai, dong is Holy Hill, pa is rock, and lai is multicolored). Based on available Landsat satellite images, Dong Palai was part of a large natural forest in 1950, but it became isolated and was reduced to 30.04 ha in 1988, and 18.37 ha in 1999 (Zhu et al. 2010). The remaining Holy Hill is 17.46 ha in size (Zeng 2012), and it is currently one of the largest in the region. Dong Palai was first surveyed by Soviet and Chinese botanists in the 1950s, and it has since been the site of numerous ecological studies (e.g., Liu et al. 2002; Zhu et al. 2004; Zhu et al. 2010; Zeng 2018b). Because of the early botanical studies in Dong Palai (Sturgeon and Menzies 2006; Zhu et al. 2010), Manyangguang was the original site of XTBG before it was moved in 1959 to its present location on the Luosuo River (Reuse 2010).

XTBG's historical presence has muddied the land tenure of Dong Palai: Holy Hill ownership was transferred to XTBG when it was there, and it is not clear that ownership ever transferred back, since village elders in the 1980s-when land was decollectivized and reallocated to communities and households after Maoist campaigns in the 1960s and 1970s (Shapiro 2001; Sturgeon 2004)—did not sign the land allocation paperwork because they were distrustful of the government at that time. This became an issue when tourism companies began approaching Manyangguang's leadership to lease Dong Palai for eco-tourism development, and it was unclear from a legal standpoint whether the community of Manyangguang had the right to lease their Holy Hill. The village head from Manyangguang insisted that "Dong Palai was protected and passed down from our ancestors, so we should be able to do what we want with it." However, local township officials and government officials from the state-owned nature reserve remained firm that "Manyangguang's Holy Hill is state-owned forest【有林】(guóyǒulín)."

Regardless of any tenuous legal standings, the village leadership of Manyangguang signed a contract to lease Dong Palai for 50 years to a tourism company on 20 October 2015 (Zeng and Reuse 2016). The lease extended from 1 January 2016 to 1 January 2066, during which the tourism company would pay an annual fee of 70,000 RMB (approximately $\$ 9900$ USD) to the village council. Dong Palai was to become a nature park as a stop along a tourist route being developed with attractions strung along the highway between Jinghong and Da Menglong. Signing this lease was a democratic decision, and at a village forum, a near unanimous village vote supported leasing Dong Palai for tourism. In signing the lease, some expressed hopes for economic opportunities. For instance, the adult daughter of a village council member told me, "It will be really good for the village to have lots of tourists coming through. I can sell things at home and run a little business." However, other community members said, "I don't think I'll see much of the benefits, like selling things to tourists. Stuff like that probably won't rotate to me. People connected to the village council will have an advantage." Despite 
this potentially variable access to economic opportunities, the village council arranged for the rent money from the Holy Hill lease to be divided equally among households, to which some community members complained, "It is not much money after it is spread across the whole village." In answer to this sentiment, one village council member responded that "Even though this is not much money, it is better than nothing, since we're keeping the Holy Hill for nothing right now" 【在就是白】(xiànzài jiùshì báiyăng). Moreover, in addition to these monetary concerns, several villagers believed that "Dong Palai will be better protected, since the tourism company plans to build a wall around the Holy Hill and hire a security guard."

People outside Manyangguang, however, did not share this perspective on eco-tourism and environmental protection. Prior to the Manyangguang leadership signing the Holy Hill lease, the vice-mayor of Manyangguang's township refused to support Manyangguang's village council in pursuing tourism development of the Holy Hill, claiming that it would harm the forest ecosystem. Despite the fact that the government and NGOs have previously supported similar projects, such as in the examples provided in the previous section of this article, several government employees and conservation researchers I spoke to were also immediately critical of Manyangguang's decision to lease their Holy Hill, claiming, "The locals do not know to protect the environment because they just want money. Their culture and religion are fading." Despite this disapprobation from official authority figures, it is worth noting that leasing Dong Palai for eco-tourism is very much in line with the official Eco-Civilization ethos of supporting cultural traditions and coupling environmental protection with economic development. Moreover, in addition to providing income from the lease and potential economic opportunities from tourism development, establishing a monetary relationship may have been a way for Manyangguang villagers to reconnect to their Holy Hill and reassert their control after decades of land tenure uncertainty and alienation due to XTBG's historical presence.

Ultimately, although Manyangguang villagers were successful in leasing their Holy Hill, interlocuters from Manyangguang and the leasing tourism company told me this project was halted in early 2017 by local government because of concerns about tourism development causing ecological degradation in the Holy Hill forest ecosystem. In other words, despite the fact that this Holy Hill had been protected by Manyangguang's community members for many generations, the government co-opted the role of environmental caretaker and removed it from Manyangguang villagers, much to the dismay of local community members. Thus, though the Chinese state is supportive of ethnic minority traditions in the Eco-Civilization rhetoric, it does not always trust ethnic minority communities to maintain their own practices in the appropriate manner to suit official narratives.

In such circumstances, it becomes necessary for ethnic minorities to navigate and articulate cultural identities for community benefits within hegemonic narratives of development and environmental protection. This is a difficult task in light of state expectations of "oppressive authenticity" for ethnic minorities, much like with indigenous peoples in various environmental narratives: "Indigenous people are expected to be essentially 'other' and to manifest this otherness in natural and visible ways. To be naturally other is to remain part of the landscape, to be intimately linked to the ecology of country like trees and rivers and animals. It is to be primitive, to live simply and close to nature" (Sissons 2005, p. 38; italics in original). Dai communities, therefore, are expected in state and development narratives to be close to nature, and their self-identified interest in expanding their market economy through eco-tourism development is anomalous and no longer culturally authentic, which consequently renders them unattractive to state and development agents. A similar dynamic has been noted in the body of conservation literature that characterizes indigenous peoples as "noble savages" living in harmony in nature, in which deviations from the "tribal slot" often lead environmentalists to portray indigenous people as enemies of nature who have lost their traditional ways (Cronon 1995; Holt 2005; Baker et al. 2013). This results in a "conservation catch-22," in which "[c]onservation awareness arises when people exert use pressure on resources and recognize the potential for overexploitation, conditions concurrent with population growth, adoption of Western technologies, and market production. This is the same transition that ironically renders local people less desirable as conservation allies in the eyes 
of biologists" (Holt 2005, p. 201). In this light, Manyangguang's predicament can perhaps be framed as a "development catch-22."

Indeed, Manyangguang's development catch-22 from its self-motivated pursuit of eco-tourism development inspired comments from Chinese state development workers that Manyangguang villagers are too "money-minded," which has resulted in lost opportunities. For example, in November 2015, I joined a scientist from the Chinese Academy of Sciences and an official from Xishuangbanna National Nature Reserve for a Holy Hill restoration planting at the Dai village of Manyuan. While I was chatting with the nature reserve official, he said, "I don't like Manyangguang. The villagers have a bad attitude towards environmental protection【他的保意不好】 (tāmen de băohù yì bù hăo). I like Manyuan village, which is why I suggested that we do this restoration project here. [The scientist] was originally planning to do this project at Manyangguang, but he switched it here at my suggestion." This was an interesting criticism of Manyangguang given that the Holy Hill restoration at Manyuan was also coupled with money-making, for it was sponsored by a Chinese traditional medicine company, and the medicinal herbs planted in the Holy Hill restoration were meant to be sold as traditional medicine to provide additional income to the village. The scientist and official were also hosting executives from doTerra, an American essential oil company, to visit Manyuan because doTerra was interested in financially supporting the project as well.

In analyzing collaborative green development initiatives, Tsing (1999) has described how the worthiness of a "tribe" (her shorthand for subjects of international thinking about exotic and backward rural communities) to access resources for development is often based on how well a tribe captures the balance of primitivism and longing for civilized change to create an "emotionally fraught space that keeps the experts coming back" (Tsing 1999, p. 161). In China, ethnic minorities are often expected to be the passive and grateful recipients of central-state-led development (Harrell 1995b; Sturgeon 2010; Yeh 2013; Yeh and Coggins 2014), and Dai in particular are typically thought of as politically and ethnically passive model minorities (Hsieh 1995; McCarthy 2009). Following this reasoning to understand Manyangguang's lack of appeal to state development agents, Manyangguang's self-directed pursuit of development opportunities, even ones that included forest conservation, failed to evoke official ideas about rural minority communities and erased potential roles for state and development agents in a collaborative arrangement; whereas Manyangguang wanted to be an active subject in its own development narrative, outside agents were looking for a passive object to be part of their development narrative. Furthermore, when Manyangguang sought agency and self-determination, refusal from outside agents highlighted a mindset in which community members were deemed unable to make responsible decisions for themselves-a power dynamic comparable to a child and parent, as I will explore in the following section.

\section{Eco-Civilization in Public Signage and Parent-Child Dynamics}

In July 2017, while stopping at my favorite Buddhist restaurant in Kunming's Lotus Pond Park, I noticed that since my last visit in 2015, the park had become densely dotted with signs promoting environmental protection and civilized behaviors, with slogans such as "Our entire society is active in purifying the environment for children to grow up" (Figure 1). As discussed previously, both sustainable development and Eco-Civilization promote balancing environmental protection and economic development, but Eco-Civilization messaging from the CPC has been distinct in its emphasis on harmonious microcosm-macrocosm relationships, which are often expressed through familial relationships. For instance, another sign at Lotus Pond Park instructed citizens to "Care for the growth of children to create a better future for the motherland" (Figure 2). Similar slogans can be found in Dai villages, with signs that proclaim, "Officials should love citizens; older generations should love children and grandchildren" (Figure 3). During my fieldwork, I noticed instances in which this mimetic relationship seemed to have permeated public consciousness. For example, when I asked one Dai villager, "What does Eco-Civilization mean?" She answered, "It means everyone treats each other well, and everyone is peaceful" —a response that describes the national political framework in terms of 
localized interpersonal relationships, and which seems to suggest national harmony as a macrocosm of familial and community harmony.

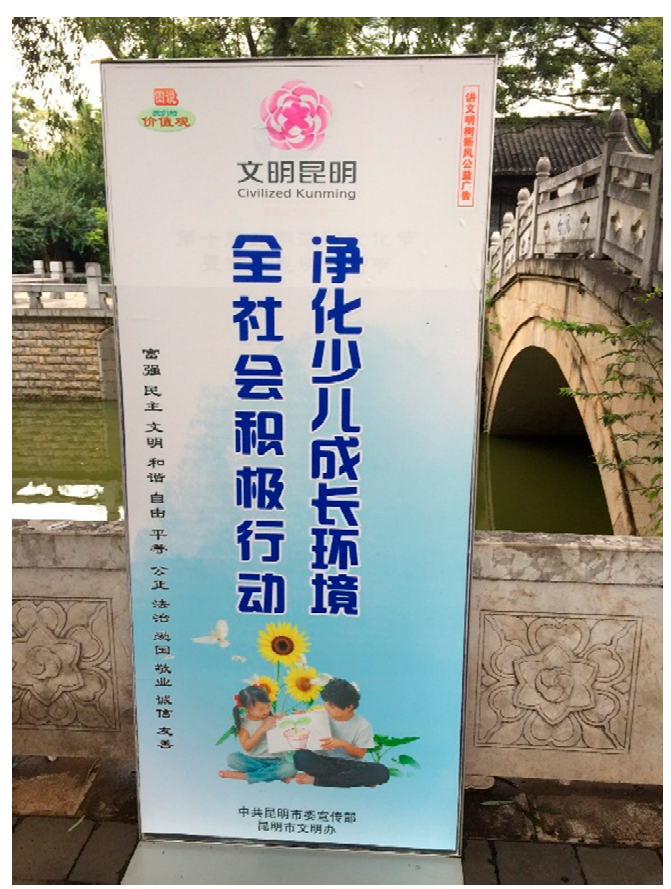

Figure 1. A Civilized Kunming sign at Lotus Pond Park: "Our entire society is active in purifying the environment for children to grow up"【全社极行, 化少儿成境】(quán shèhuì jijjí xíngdòng, jinghuà shào'ér chéngzhăng huánjìng).

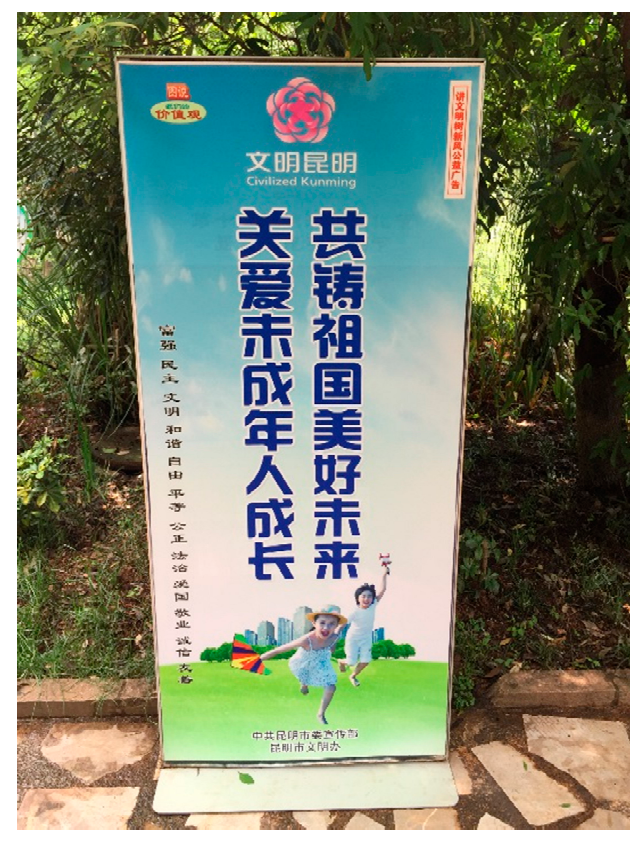

Figure 2. A Civilized Kunming sign at Lotus Pond Park: "Care for the growth of children to create a better future for the motherland”【未成年人成, 共祖美好未】 (guān'ài wèi chéngnián rén chéngzhăng, gòng zhù zǔguó měihăo wèilái). 


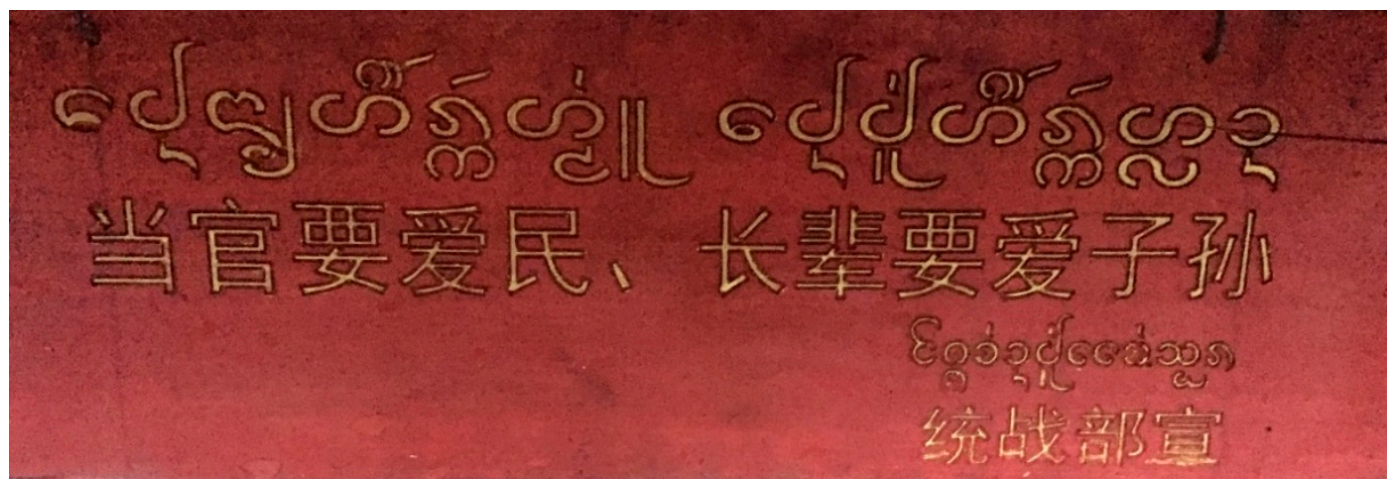

Figure 3. A sign in Manlang village: “Officials should love citizens; older generations should love children and grandchildren”【官要民, 要子】 (dāng guān yào àimín, zhăngbèi yào ài ž̌sūn).

Drawing familial connections is a familiar approach in Chinese political spheres, and especially with ethnic minorities, scholars have noted a tendency to include childlike elements in popular imagery (Harrell 1995a; Schein 1997; Davis 2005). For instance, Louisa Schein has described a 1984 poster in which "[1]iterally infantilized minority children, again in full festival regalia, some holding toys and some holding musical instruments, along with one or two Han, were shown playing gleefully with, holding the hands of, or even embracing a fatherly Mao Zedong, Zhou Enlai, Liu Shaoqi, and Zhu De" (Schein 1997, p. 90). In Xishuangbanna, Sara Davis has described Jinghong's Nationalities Theme Park as she observed in the late 1990s, which displayed "a series of discrete ethnic groups living happily under the shadow of a towering monument that symbolizes the nation-state ... The villages are small, bounded clusters of miniature stilt houses.... The miniaturization of ethnic homes reduces ethnic peoples to the status of children, enhancing the status of the visitor" (Davis 2005, pp. 32-34). More recently, during the Opening Ceremony of the 2008 Beijing Olympics, China's 55 officially recognized ethnic minorities were represented by actual children wearing traditional ethnic garb and carrying the Chinese flag into the Bird's Nest National Stadium. ${ }^{11}$ These images introduce "a generational element to emphasize this paternalistic role of the Party ... [that] invoke[s] a Confucian vision of authority-the first employing the elder sibling-younger sibling relationship, the second conflating the father-child relation with that of the emperor-subject-to emphasize the ascendancy of the Han state" (Schein 1997, p. 90). Moreover, portraying ethnic minorities as children is a key tactic in civilizing projects:

it not only demonstrates the inferiority of peripheral peoples, but also certifies their civilizability, and thus legitimates not just domination but the particular kind of domination we call a civilizing project. ... since children are by definition both inferior and educable, the peripheral peoples represented as childlike are both inferior and civilizable, and it becomes the task of the center to civilize them. (Harrell 1995a, p. 13)

In addition to justifying the civilizing project, this parent-child or elder-younger sibling metaphor has resulted in a political mentality in Xishuangbanna such that "The state has adopted a kind of caretaker relationship toward Dai cultural practice, and the preservation of Dai culture is viewed as an end in itself" (McCarthy 2009, p. 72). This caretaker attitude was apparent in the previous section with the local government's reluctance allow Manyangguang's Holy Hill eco-tourism project to proceed despite its ostensible accordance with popular state rhetoric for Eco-Civilization, or the nature reserve official taking action to divert the Holy Hill restoration project away from Manyangguang to punish this community for what he saw as cultural improprieties in their ambitions for economic development. Children cannot always be trusted to make appropriate decisions without adult supervision; thus, it was

11 It was later revealed that these children were not in fact from the various ethnic minority groups; they were Han children wearing costumes representing each ethnic minority (Spencer 2008). 
incumbent upon state officials to step in and make responsible choices on behalf of Manyangguang. Moreover, this parent-child dynamic also serves to support the multicultural national unity sought after by the CPC, while maintaining the privileged position of the state: parents and children comprise one family, but the parents know best and make major decisions on behalf of younger (or inferior) family members.

In official political discourse, the state's parent or caretaker role includes responsibilities to curate and improve "excellent and non-excellent elements [of cultural traditions]. Though the former are deemed worth continuing and developing, the latter must be abolished and reformed" (Hasegawa 2000, p. 132). With Dai people in Xishuangbanna, Sara Davis has described government involvement in ethnic folklore by which "[d]ances and oral literature were studied and in some cases 'improved' by state choreographers and authors" (Davis 2005, p. 19), among other similar examples. These same principles were applied in 2017 by the United Front Work Department【部】 (tǒngzhàn bù), a federal agency devoted to promoting national unity, when it provided funding to local government offices to install signs in certain Dai communities that proclaimed its goal to "Strengthen the management of religious affairs according to law, and actively guide the religion to adapt to socialism" (Figure 4).

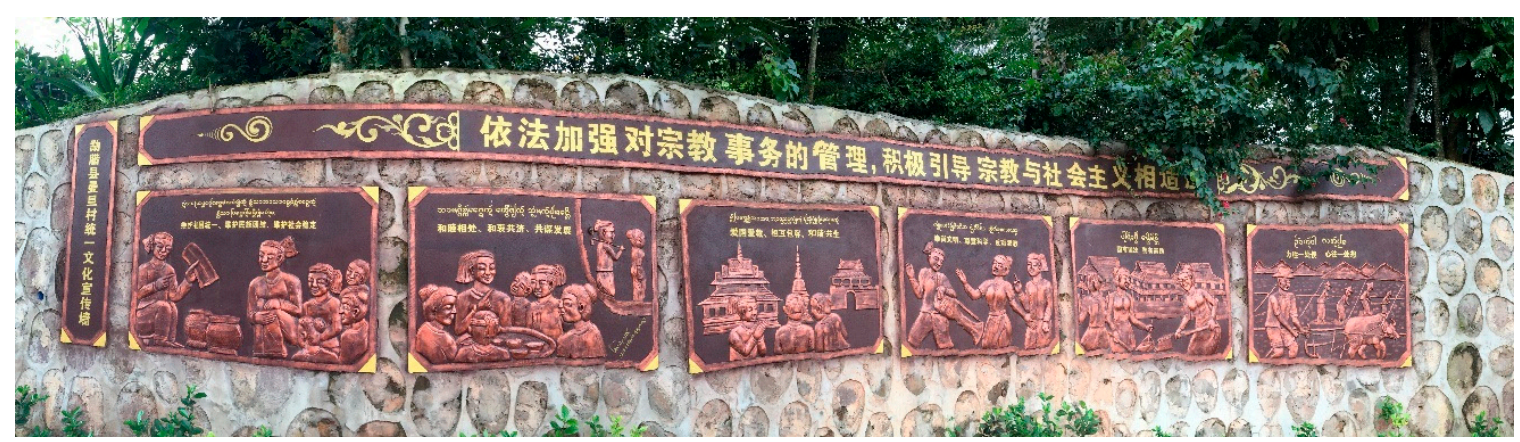

Figure 4. A sign in Mandan village. The text along the top reads: "Strengthen the management of religious affairs according to law, and actively guide the religion to adapt to socialism” 【依法加宗教事 的管理, 极引宗教与社主相适】 (yĩfă jiāqiáng duì zōngjiào shìwù de guănlǐ, jījí yǐndăo zōngjiào yǔ shèhuì zhǔyì xiāng shìying).

These signs contain government-approved "traditional Dai sayings," such as "Only with forests is there water, only with water are there rice paddies, only with rice paddies is there food, only with food are there people" (Figure 5). This Dai saying has also been widely popularized in academic circles and among environmental practitioners by Pei Shengji (e.g., Pei 2010) in his writing to connect Dai identity with traditional ecological knowledge and indigeneity (Hathaway 2013).

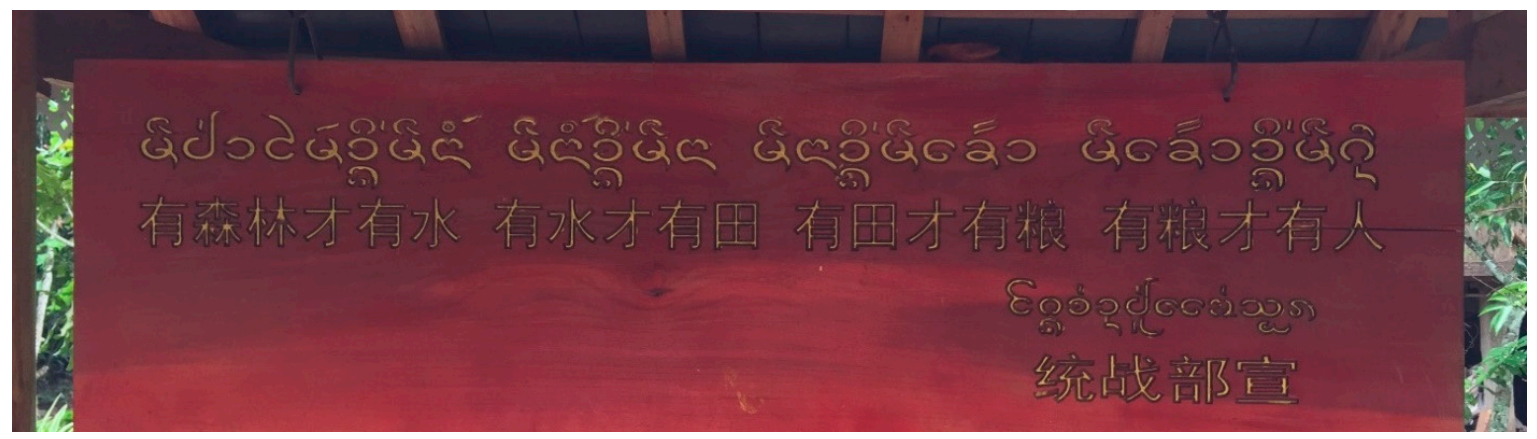

Figure 5. A sign in Manlang village: "Only with forests is there water, only with water are there rice paddies, only with rice paddies is there food, only with food are there people" 【有森林才有水, 有水 才有田, 有田才有, 有才有人】 (yǒu sēnlín cái yǒu shǔ̌, yǒu shuľ cái yǒutián, yǒutián cái yǒu liáng, yǒu liáng cái yǒurén). 
To ground-truth whether these signs actually contain old Dai sayings, I showed them to a former abbot and excellent Dai scholar trained at several educational institutions, including not only temples in Xishuangbanna, but also temples and universities in Southeast Asia, as well as Columbia University in the USA. In reference to the aforementioned quote, he told me this is indeed an old Dai saying, but the government modified it slightly to "sound prettier." The original wording, which he translated to Mandarin Chinese during our conversation, is "Only with water are there fish, only with rice paddies is there food, only with food are there people" 【有水才有, 有田才有, 有才有人】 (yǒu shuǐ cái yǒu yú, yǒutián cái yǒu liáng, yǒu liáng cái yǒurén). Although the ethos of human dependence on the natural environment remains the same, the government-approved version includes an explicit connection between forests and water-much like in the Sloping Land Conversion Program, initiated by the central government in 1999, which was designed to protect waterways and reduce soil erosion by increasing China's forest cover. However, it should be noted that although the forest-water connection was absent in the wording of the original Dai saying, the idea that "big trees protect water"-what many scientists refer to as watershed forestry-was still prevalent among Dai villagers, who often mentioned this fact as they showed me around various forests and nearby waterways.

There are other Dai sayings whose underlying ethos had been modified more overtly to suit government. In the aforementioned sign which reads, "Officials should love citizens; older generations should love children and grandchildren" (Figure 3), the original wording in Dai (haak moo) means to love "our group" rather than "citizens," the latter of which is a term with explicit ties to the governance of the Chinese state. Moreover, within this same format of public signage, there is also government messaging with no ties to any traditional Dai sayings. For instance, the slogan "Ethnic groups should cooperate with the power of national unity to create a harmonious civilization in Xishuangbanna" (Figure 6) is clear propaganda for the government agenda. Similarly, with "Advocate civilization, respect science, oppose cults" (Figure 7), the ideas presented here (e.g., science, cults) are anachronistic for Buddhist teachings, and the wording choices (e.g., civilization) are obviously mirroring current CPC messaging.

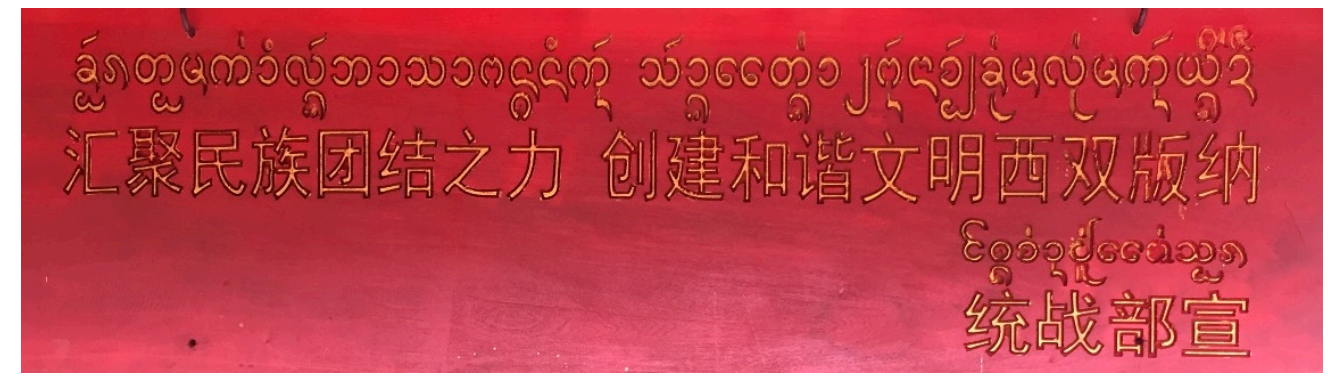

Figure 6. A sign in Manlang village: "Ethnic groups should cooperate with the power of national unity to create a harmonious civilization in Xishuangbanna"【聚民族之力 建和文明西版】[huijù mínzú tuánjié zhī lì chuàngjiàn héxié wénming xīshuāngbănnà].

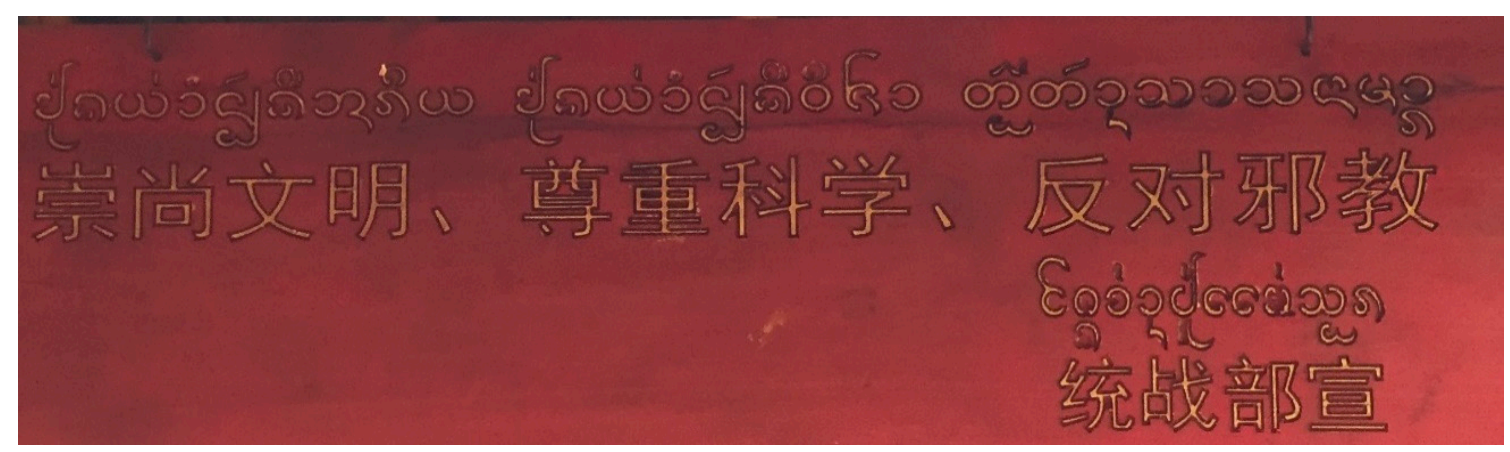

Figure 7. A sign in Manlang village: “Advocate civilization, respect science, oppose cults”【崇尚文 明、尊重科、反邪教】[chóngshàng wénminng, zūnzhòng kēxué, fănduì xiéjiào]. 
Nevertheless, when I spoke to Dai villagers, many of my interlocuters could not discern the difference between an original Dai saying, which they attributed to Buddhist sutras, and government-modified ones-nor, to be honest, did they seem particularly bothered by the distinction. It would be difficult, however, to generalize any "typical" Dai reactions to these altered sayings. Other scholars have described instances in which individuals distinguish sharply between "real" and "fake" Dai cultural representations (e.g., Davis 2005; McCarthy 2009), whereas my own fieldwork experiences often revealed unquestioning acceptance of CPC narratives, a self-admitted lack of knowledge, or differences of opinion among Dai interlocuters as to who or what determines authenticity and why it does or does not matter. One possible reason for this confusion may be the destruction of many temples as institutions of Dai cultural learning during the Maoist era (Davis 2005; Borchert 2008), creating a generational cultural knowledge gap that I heard many Dai elders lament during my fieldwork. Or perhaps many Dai villagers expressed such apathy to the signage because it does not constitute a core part of their culture. Dai people know that the CPC must be appeased, like any parent or guardian figure, in order for them to continue participating in the cultural revival efforts that they find genuinely meaningful, such as transnational exchanges of pop music and monk trainees, as well as restoring religious institutions like temples and Holy Hills (Davis 2005; Borchert 2008; McCarthy 2009; Zeng 2018a).

\section{Conclusions}

China's rapid economic growth in a few short decades has accelerated staggering environmental problems affecting the everyday lives of many citizens, and in response, the CPC has championed Eco-Civilization as its political framework to align China's economic growth with environmental protection. Alongside its commitment to economic prosperity and environmental well-being, a key priority for the Chinese state is also to manage its multi-ethnic citizens and strengthen national unity. Following the Chinese Revolution, the CPC had categorized its heterogenous population into 56 ethnic groups, and inspired by Soviet ideology and practice, it ranked the majority Han and 55 ethnic minorities according to a linear schema of social value in which the Han were deemed the zenith of civilization, while ethnic minorities were considered backwards and in need of state-led development. These ideas of ethnic difference and intrinsic social value were layered onto past political decisions about economic development and environmental protection, as I have illustrated with the examples of rubber cultivation and swidden agriculture in Xishuangbanna, and they continue to permeate current Eco-Civilization ideology. Though Eco-Civilization has ostensibly portrayed many ethnic minority cultures in a positive way that is compatible with the CPC's vision of China's future, many of the institutions and activities that it inspires retain problematic power dynamics that often reinforce inequalities between the Han civilizing center and peripheral ethnic minorities. This has resulted in instances under the Eco-Civilization framework in which Dai people were not trusted as caretakers of their own culture, as I have explored with the case of Holy Hill eco-tourism pursued by the Dai village of Manyangguang, resulting in a "development catch-22." Moreover, other Eco-Civilizations efforts, such as public signage, have reinforced a parent-child dynamic between Chinese state and ethnic minorities, which is used not only to justify civilizing projects, but also to solidify CPC interests by promoting national unity in conjunction with a strong rationale for state control.

Thus, though its ethos has many attractive elements of simultaneously supporting economic development and environmental protection by embracing cultural traditions and national unity, in practice many efforts feeding into the Eco-Civilization rhetoric have resulted in questionable environmental benefits (such as the case with rubber) and used the guise of supporting ethnic cultural traditions to instead further entrench state ascendency while disenfranchising already marginalized ethnic minorities. Moreover, Eco-Civilization discourse will likely gain in importance as the Chinese political leadership continues its efforts for a more positive global image through strong leadership in environmental governance. Though this paper has primarily focused on Dai people in Xishuangbanna, the issues and dynamics explored here with Eco-Civilization and similar political frameworks are 
not limited to this ethnic group, nor to ethnic minorities and rural populations, for as this article has intimated, Han identity in central powers is unquestionably shaped reciprocally by its relationships to those defined by top-down and state-led ideologies of ethnic identity. These topics certainly warrant further inquiry and exploration with other groups and geographic areas in China, especially as both China and environmental concerns gain a larger presence on the international stage.

Funding: This research was funded by the U.S. National Science Foundation (NSF) Graduate Research Fellowship, Natural Sciences and Engineering Research Council of Canada (NSERC) Postgraduate Scholarship for Doctoral Students, National Geographic Young Explorer Grant, and New York Botanical Garden Lewis B. and Dorothy Cullman Fellowship.

Conflicts of Interest: The author declares no conflict of interest.

\section{References}

Ahlers, Anna L., and Yongdong Shen. 2018. Breathe Easy? Local Nuances of Authoritarian Environmentalism in China's Battle against Air Pollution. China Quarterly 234: 299-319. [CrossRef]

Anagnost, Ann. 2004. The Corporeal Politics of Quality (Suzhi). Public Culture 16: 189-208. [CrossRef]

Baker, Lauren, Michael Dove, Dana Graef, Alder Keleman, David Kneas, Sarah Osterhoudt, and Jeffrey Stoike. 2013. Whose Diversity Counts? The Politics and Paradoxes of Modern Diversity. Sustainability 5: 2495-518. [CrossRef]

Bernstein, Steven. 2001. The Compromise of Liberal Environmentalism. New York: Columbia University Press.

Borchert, Thomas. 2008. Worry for the Dai Nation: Sipsongpannā, Chinese Modernity, and the Problems of Buddhist Modernism. The Journal of Asian Studies 67: 107-42. [CrossRef]

Cao, Min, Hu Huabin, Yong Tang, and Xianhui Fu. 2000. Human Dimension of Tropical Forest in Xishuangbanna, SW China. In 2000 Seminar on Ecosystem Research and Sustainable Management. Seoul: Korea Long-Term Ecological Research Network.

Chen, Huafang, Zhuangfang Yi, Dietrich Schmidt-Vogt, Antje Ahrends, Philip Beckschäfer, Christoph Kleinn, Sailesh Ranjitkar, and Jianchu Xu. 2016. Pushing the Limits: The Pattern and Dynamics of Rubber Monoculture Expansion in Xishuangbanna, SW China. PLoS ONE 11: 1-15. [CrossRef] [PubMed]

Commercon, Francis. 2016. Local Knowledge for Restoration in a Rubber-Dominated Landscape in SW China. Available online: http://blog.worldagroforestry.org/index.php/2016/01/26/local-knowledge-for-restorationin-a-rubber-dominated-landscape-in-china/ (accessed on 8 September 2016).

Conklin, Harold C. 1954. An Ethnoecological Approach to Shifting Agriculture. Transactions of the New York Academy of Sciences II 17: 133-42. [CrossRef]

Conklin, Harold C. 1957. Hanunóo Agriculture: A Report on an Integral System of Shifting Cultivation in the Philippines. Rome: Food and Agriculture Organization of the United Nations.

Cronon, William. 1995. The Trouble with Wilderness: Or, Getting Back to the Wrong Nature. Environmental History 1: 7-28. [CrossRef]

Crossley, Pamela Kyle, Helen F. Siu, and Donald S. Sutton, eds. 2006. Empire at the Margins: Culture, Ethnicity, and Frontier in Early Modern China. Oakland: University of California Press.

Davis, Sara L. M. 2005. Song and Silence: Ethnic Revival on China's Southwest Borders. New York: Columbia University Press.

Delman, Jørgen. 2018. Ecological Civilization Politics and Governance in Hangzhou: New Pathways to Green Urban Development? Asia-Pacific Journal: Japan Focus 16: 1-21.

Dove, Michael R. 1983. Theories of Swidden Agriculture, and the Political Economy of Ignorance. Agroforestry Systems 1: 85-99. [CrossRef]

Dove, Michael R. 2018. Rubber versus Forest on Contested Asian Land. Nature Plants 4: 321-22. [CrossRef]

Duara, Prasenjit. 2001. The Discourse of Civilization and Pan-Asianism. Journal of World History 12: 99-130. [CrossRef]

Duara, Prasenjit. 2014. The Crisis of Global Modernity: Asian Traditions and a Sustainable Future. Cambridge: Cambridge University Press.

Dynon, Nicholas. 2008. 'Four Civilizations' and the Evolution of Post-Mao Chinese Socialist Ideology. China Journal 60: 83-109. [CrossRef] 
Evans, Grant. 2000. Transformation of Jinghong, Xishuangbanna, PRC. In Where China Meets Southeast Asia: Social and Cultural Change in the Border Regions. Edited by Grant Evans, Christopher Hutton and Kuah Khun Eng. New York: St. Martin's Press, pp. 162-82.

Fabian, Johannes. 1983. Time and the Other: How Anthropology Makes Its Object. New York: Columbia University Press.

Gao, Lishi. 2010. A Study of the Long Forest Culture of the Dai People. Kunming: Yunnan Minzu Publisher.

Giersch, C. Patterson. 2006. Asian Borderland: The Transformation of Qing China's Yunnan Frontier. Cambridge: Harvard University Press.

Gladney, Dru C. 2004. Dislocating China: Muslims, Minorities, and Other Subaltern Subjects. Chicago: University of Chicago Press.

Guo, Huijun, and Christine Padoch. 1995. Patterns and Management of Agroforestry Systems in Yunnan: An Approach to Upland Rural Development. Global Environmental Change 5: 273-79. [CrossRef]

Guo, Huijin, Christine Padoch, Kevin Coffey, Chen Aiguo, and Fu Yongneng. 2002. Economic Development, Land Use and Biodiversity Change in the Tropical Mountains of Xishuangbanna, Yunnan, Southwest China. Environmental Science \& Policy 5: 471-79. [CrossRef]

Hansen, Mette Halskov. 1999. Lessons in Being Chinese: Minority Education and Ethnic Identity in Southwest China. Seattle: University of Washington Press.

Hansen, Mette Halskov. 2005. Frontier People: Han Settlers in Minority Areas of China. Vancouver: University of British Columbia Press.

Hansen, Mette Halskov, and Zhaohui Liu. 2018. Air Pollution and Grassroots Echoes of 'Ecological Civilization' in Rural China. China Quarterly 234: 320-39. [CrossRef]

Hansen, Mette Halskov, Hongtao Li, and Rune Svarverud. 2018. Ecological Civilization: Interpreting the Chinese Past, Projecting the Global Future. Global Environmental Change 53: 195-203. [CrossRef]

Harrell, Stevan. 1995a. Civilizing Projects and the Reaction to Them. In Cultural Encounters on China's Ethnic Frontiers. Edited by Stevan Harrell. Seattle: University of Washington Press, pp. 3-36.

Harrell, Stevan, ed. 1995b. Cultural Encounters on China Ethnic Frontiers. Seattle and London: University of Washington Press.

Harris, Paul G., and Graeme Lang, eds. 2015. Routledge Handbook of Environment and Society in Asia. Abingdon: Routledge.

Hasegawa, Kiyoshi. 2000. Cultural Revival and Ethnicity: The Case of the Tai Lüe in the Sipsong Panna, Yunnan Province. In Dynamics of Ethnic Cultures Across National Boundaries in Southwestern China and Mainland Southeast Asia: Relations, Societies and Languages. Edited by Yukio Hayashi and Guangyuan Yang. Chiang Mai: Ming Muang Publishing House, pp. 121-37.

Hathaway, Michael J. 2013. Environmental Winds: Making the Global in Southwest China. Berkeley: University of California Press.

Holt, Flora Lu. 2005. The Catch-22 of Conservation: Indigenous Peoples, Biologists, and Cultural Change. Human Ecology 33: 199-215. [CrossRef]

Hsieh, Shih-Chung. 1995. On the Dynamics of Tai/Dai-Lue Ethnicity: An Ethnohistorical Analysis. In Cultural Encounters on China's Ethnic Frontier. Edited by Stevan Harrell. Seattle: University of Washington Press, pp. 301-28.

$\mathrm{Hu}$, Huabin, Wenjun Liu, and Min Cao. 2008. Impact of Land Use and Land Cover Changes on Ecosystem Services in Menglun, Xishuangbanna, Southwest China. Environmental Monitoring and Assessment 146: 147-56. [CrossRef]

Keyes, Charles F. 1992. Who Are the Lue? Revisited: Ethnic Identity in Laos, Thailand, and China. In Working Paper, Massachusetts Institute of Technology, Center for International Studies. Cambridge: Massachusetts Institute of Technology Center for International Studies.

Keyes, Charles F. 1995. Who Are the Tai? Reflections on the Invention of Identities. In Ethnic Identity: Creation, Conflict and Accommodation, 3rd ed. Edited by Lola Romanucci-Ross and George A. De Vos. Walnut Creek: AltaMira Press, pp. 130-60.

Kostka, Genia, and Jonas Nahm. 2017. Central-Local Relations: Recentralization and Environmental Governance in China. China Quarterly 231: 567-82. [CrossRef] 
Kou, Z. T., and H. Zhang. 1987. A Herpetological Report of Xishuangbanna. In Proceedings of Synthetical Investigation of Xishuangbanna Nature Reserves. Kunming: Yunnan Science and Technology Press, pp. 350-68.

Lélé, Sharachchandra M. 1991. Sustainable Development: A Critical Review. World Development 19: 607-21. [CrossRef]

Li, Hongmei, T. Mitchell Aide, Youxin Ma, Wenjun Liu, and Min Cao. 2007. Demand for Rubber Is Causing the Loss of High Diversity Rain Forest in SW China. Biodiversity and Conservation 16: 1731-45. [CrossRef]

Litzinger, Ralph A. 2000. Other Chinas: The Yao and the Politics of National Belonging. Durham: Duke University Press.

Liu, Hongmao, Zaifu Xu, Youkai Xu, and Jinxiu Wang. 2002. Practice of Conserving Plant Diversity through Traditional Beliefs: A Case Study in Xishuangbanna, Southwest China. Biodiversity and Conservation 11: 705-13. [CrossRef]

McCarthy, Susan K. 2009. Communist Multiculturalism: Ethnic Revival in Southwest China. Seattle: University of Washington Press.

Min, Shi, Jikun Huang, Junfei Bai, and Hermann Waibel. 2017. Adoption of Intercropping among Smallholder Rubber Farmers in Xishuangbanna, China. International Journal of Agricultural Sustainability 15: 223-37. [CrossRef]

Mo, Xiao Xue, Hua Zhu, Yong Jiang Zhang, J. W. Ferry Slik, and Jing Xin Liu. 2011. Traditional Forest Management Has Limited Impact on Plant Diversity and Composition in a Tropical Seasonal Rainforest in SW China. Biological Conservation 144: 1832-40. [CrossRef]

Mullaney, Thomas S. 2010. Coming to Terms with the Nation: Ethnic Classification in Modern China. Berkeley: University of California Press.

Myers, Norman, Russell A. Mittermeier, Cristina G. Mittermeier, Gustavo A. B. da Fonseca, and Jennifer Kent. 2000. Biodiversity Hotspots for Conservation Priorities. Nature 403: 853-58. [CrossRef]

Oswald, James P. F. 2014. What Does Eco-Civilisation 生文明 Mean? The China Story Journal 4: 2014.

Pei, Shengji. 1985. Preliminary Study of Ethnobotany in Xishuang Banna, People's Republic of China. Journal of Ethnopharmacology 13: 121-37. [CrossRef]

Pei, Shengji. 1993. Managing for Biological Diversity in Temple Yards and Holy Hills: The Traditional Practices of the Xishuangbanna Dai Community, Southwestern China. In Ethics, Religion, and Biodiversity: Relations between Conservation and Cultural Values. Edited by Lawrence S. Hamilton and Helen F. Takeuchi. Cambridge: White Horse Press, pp. 112-18.

Pei, Shengji. 2010. The Road to the Future? The Biocultural Values of the Holy Hill Forests of Yunnan Province, China. In Sacred Natural Sites: Conserving Nature and Culture. Edited by Bas Verschuuren. Abingdon-on-Thames: Routledge, pp. 98-106.

Pei, Shengji, and Jianchu Xu. 1997. Biodiversity and Sustainability in Swidden Agroecosystems: Problems and Opportunities (a Synthesis). In Collected Research Papers on Biodiversity in Swidden Agroecosystems in Xishuangbanna. Edited by Shengji Pei. Kunming: Yunnan Education Publishing House, pp. 173-77.

Penot, Eric, Bénédicte Chambon, and Gede Wibawa. 2017. History of Rubber Agroforestry Systems Development in Indonesia and Thailand as Alternatives for Sustainable Agriculture and Income Stability. International Proceedings of IRC 2017 1: 497-532. [CrossRef]

Qiu, Jane. 2009. Where the Rubber Meets the Garden. Nature 457: 246-47. [CrossRef]

Ramachandran, Pavit. 2005. Xishuangbanna Biodiversity Conservation Corridors Project. People's Republic of China: Pilot Site Project Profile, Bangkok: Asian Development Bank.

Reuse, Gaetan. 2010. Secularization of Sacred Space: An Analysis of Dai Farmers Planting Rubber Trees on Holy Hills in Xishuangbanna. Master's thesis, Simon Fraser University, Yunnan, China.

Saint-Pierre, C. 1991. Evolution of Agroforestry in the Xishuangbanna Region of Tropical China. Agroforestry Systems 13: 159-76. [CrossRef]

Sawyer, Jon. 2015. Ecological Civilization: Proceedings, International Conference on Ecological Civilization and Environmental Reporting. Beijing: Yale Center Beijing.

Schein, Louisa. 1997. Gender and Internal Orientalism in China. Modern China 23: 69-98. [CrossRef]

Shapiro, Judith. 2001. Mao's War against Nature: Politics and the Environment in Revolutionary China. Cambridge: Cambridge University Press.

Shen, Qingji. 2013. Study on New Urbanization Based on Ecological Civilization. Urban Planning Forum 206: $29-36$. 
Sissons, Jeffrey. 2005. First Peoples: Indigenous Cultures and Their Futures. London: Reaktion Books.

Spence, Mark David. 1999. Dispossessing the Wilderness: Indian Removal and the Making of the National Parks. Oxford: Oxford University Press.

Spencer, Richard. 2008. Beijing Olympics: 'Ethnic' Children Revealed as Fakes in Opening Ceremony. The Telegraph, August 15.

Sturgeon, Janet C. 2004. Post-Socialist Property Rights for Akha in China: What Is at Stake? Conservation E Society 2: 137-61.

Sturgeon, Janet C. 2010. Governing Minorities and Development in Xishuangbanna, China: Akha and Dai Rubber Farmers as Entrepreneurs. Geoforum 41: 318-28. [CrossRef]

Sturgeon, Janet C., and Nicholas Menzies. 2006. Ideological Landscapes: Rubber in Xishuangbanna, Yunnan, 1950 to 2007. Asian Geographer 25: 21-37. [CrossRef]

Sturgeon, Janet C., Nicholas K. Menzies, and Noah Schillo. 2014. Ecological Governance of Rubber in Xishuangbanna, China. Conservation and Society 12: 376. [CrossRef]

Thøgersen, Stig. 2003. Parasites or Civilisers: The Legitimacy of the Chinese Communist Party in Rural Areas. China: An International Journal 1: 200-23. [CrossRef]

Thøgersen, Stig. 2009. Revisiting a Dramatic Triangle: The State, Villagers, and Social Activists in Chinese Rural Reconstruction Projects. Journal of Current Chinese Affairs 38: 9-33. [CrossRef]

Tsing, Anna. 1999. Becoming a Tribal Elder, and Other Green Development Fantasies. In Transforming the Indonesian Uplands: Marginality, Power, and Production. Amsterdam: Harwood Academic Publishers, pp. 159-202.

UNEP. 2016. Green is Gold: The Strategy and Actions of China's Ecological Civilization. Nairobi: UNEP.

Wang, Gungwu. 1984. The Chinese Urge to Civilize: Reflections on Change. Journal of Asian History 18: 1-34.

Wang, Fayun, and Qiwu Duan. 1996. Helping Local People Establish an Ecological Model Village. Yunnan Daily Report, March 11. (In Chinese)

Wang, T., and B. Jin. 1987. Mammals in Xishuangbanna Area and a Brief Survey of Its Fauna. In Proceedings of Synthetical Investigation of Xishuangbanna Nature Reserves. Edited by Y. Xu, H. Jiang and F. Quan. Kunming: Yunnan Science and Technology Press, pp. 289-304.

Wang, Zhijun, and Stephen S. Young. 2003. Differences in Bird Diversity between Two Swidden Agricultural Sites in Mountainous Terrain, Xishuangbanna, Yunnan, China. Biological Conservation 110: 231-43. [CrossRef]

Wang, Gungwu, and Yongnian Zheng. 2000. Reform, Legitimacy, and Dilemmas: China's Politics and Society. Singapore: Singapore University Press and World Scientific.

Wen, Tiejun, Kinchi Lau, Cunwang Cheng, Huili He, and Jiansheng Qiu. 2012. Ecological Civilization, Indigenous Culture, and Rural Reconstruction in China. Monthly Review 63: 29-35.

Wu, Zhaolu, Hongmao Liu, and Linyun Liu. 2001. Rubber Cultivation and Sustainable Development in Xishuangbanna, China. International Journal of Sustainable Development E World Ecology 8: 337-45. [CrossRef]

Xu, Jianchu. 2006. The Political, Social, and Ecological Transformation of a Landscape. Mountain Research and Development 26: 254-62. [CrossRef]

Xu, Jianchu, Shengji Pei, and Sanyang Chen. 1997. Indigenous Swidden Agroecosystems in Mengsong Hani Community. In Collected Research Papers on Biodiversity in Swidden Agroecosystems in Xishuangbanna. Kunming: Yunnan Education Press, pp. 26-33.

Xu, Jianchu, Jefferson Fox, Lu Xing, Nancy Podger, Stephen Leisz, and Ai Xihui. 1999. Effects of Swidden Cultivation, State Policies, and Customary Institutions on Land Cover in a Hani Village, Yunnan, China. Mountain Research and Development 19: 123. [CrossRef]

Xu, Jianchu, Erzi T. Ma, Duojie Tashi, Fu Yongshou, Lu Zhi, and David Melick. 2005. Integrating Sacred Knowledge for Conservation Culture and Land Scape in Southwest China. Ecology and Society 10: 7. [CrossRef]

Yang, Y., T. Xie, Y. Duan, W. Xu, and H. Zhu. 1987. On Birds from Xishuangbanna. In Proceedings of Synthetical Investigation of Xishuangbanna Nature Reserves. Edited by Y. Xu, H. Jiang and F. Quan. Kunming: Yunnan Science and Technology Press, pp. 326-30.

Yeh, Emily T. 2013. Taming Tibet: Landscape Transformation and the Gift of Chinese Development. Ithaca: Cornell University Press.

Yeh, Emily T., and Christopher R. Coggins, eds. 2014. Mapping Shangrila: Contested Landscapes in the Sino-Tibetan Borderlands. Seattle: University of Washington Press.

Yin, Shaoting. 2001. People and Forests: Yunnan Swidden Agriculture in Human-Ecological Perspective. Kunming: Yunnan Education Publishing House. 
Zeng, Lily. 2012. Dai Holy Hills: Potential Sanctuaries of Botanical Biodiversity in Xishuangbanna, SW China. New Haven: Yale University.

Zeng, Lily. 2018a. Problematizing Ideas of Purity and Timelessness in the Conservation Narratives of Sacred Groves in Xishuangbanna, China. Journal for the Study of Religion, Nature and Culture 12: 172-200. [CrossRef]

Zeng, Lily. 2018b. Transformations of Indigenous Identity and Changing Meanings of Sacred Nature in Xishuangbanna, China. Ph.D. dissertation, Yale University, New Haven.

Zeng, Lily, and Gaetan Reuse. 2016. Holy Hills: Sanctuaries of Biodiversity in Xishuangbanna, Southwest China. In Asian Sacred Natural Sites: Philosophy and Practice in Protected Areas and Conservation. Edited by Bas Verschuuren and Naoya Furuta. London: Routledge, pp. 194-205.

Zeng, Lily, Deepti Chatti, Chris Hebdon, and Michael R. Dove. 2017. The Political Ecology of Knowledge and Ignorance. Brown Journal of World Affairs 23: 159-76.

Zhang, Jianhou, and Min Cao. 1995. Tropical Forest Vegetation of Xishuangbanna, SW China and Its Secondary Changes, with Special Reference to Some Problems in Local Nature Conservation. Biological Conservation 73: 229-38. [CrossRef]

Zhang, Jia-Qi, Richard T. Corlett, and Deli Zhai. 2019. After the Rubber Boom: Good News and Bad News for Biodiversity in Xishuangbanna, Yunnan, China. Regional Environmental Change 19: 1713-24. [CrossRef]

Zhu, H., Z. F. Xu, H. Wang, and B. G. Li. 2004. Tropical Rain Forest Fragmentation and Its Ecological and Species Diversity Changes in Southern Yunnan. Biodiversity and Conservation 13: 1355-72. [CrossRef]

Zhu, H., H. Wang, and S. S. Zhou. 2010. Species Diversity, Floristic Composition and Physiognomy Changes in a Rainforest Remnant in Southern Yunnan, China after 48 Years. Journal of Tropical Forest Science 22: 49-66.

Ziegler, Alan D., Jefferson M. Fox, and Jianchu Xu. 2009. The Rubber Juggernaut. Science 324: 1024-25. [CrossRef] [PubMed]

(C) 2019 by the author. Licensee MDPI, Basel, Switzerland. This article is an open access article distributed under the terms and conditions of the Creative Commons Attribution (CC BY) license (http://creativecommons.org/licenses/by/4.0/). 